\title{
Aortic complications after bariatric surgery
}

\author{
Complicações da aorta pós-cirurgia bariátrica
}

Diego Felipe GAIA ${ }^{1}$, José Honório PALMA², João Nelson Rodrigues BRANCO ${ }^{3}$, Enio BUFFOLO ${ }^{4}$

RBCCV 44205-1009

\section{Abstract}

Obesity and its correlated comorbities are nowadays considered a public health concern. In the last few years a myriad of strategies searched an effective procedure to reduce weight and decreases related comorbities. Among these strategies, the bariatric procedures have been achieved a significantly increase, being able to promote an expressive and lasting weight reduction. Diverse early and late complications are described and related to restrictive and malabsortive bariatric procedures. In this report we describe two cases of cardiovascular complications (aortic dissection and aneurysm) in the late postoperative period of the bariatric procedures.

Descriptors: Aorta/surgery. Bariatric surgery/ adverse effects. Aortic aneurysm/etiology. Aneurysm, dissecting.

\section{INTRODUCTION}

Comorbidities caused by obesity have been the focus of researches seeking to mitigate them. Obesity is currently considered a public health problem, not only in developed countries but also in developing countries as well. An increasing portion of the population has been affected, including not only adults, but also children as well [1]. It is classically correlated with cardiovascular problems like coronary disease and the development of risk factors, such as dyslipidemia, hypertension, among others.

Seeking these objectives, several therapeutics have been proposed such as: diets, medications, dietary reeducation programme, physical exercises, and bariatric

1. Master Degree; Physician; Discipline of Cardiovascular Surgery.

2. Professor Livre docente; Professor of Cardiovascular Surgery Discipline - UNIFESP - Paulista Medical School.

3. Professor Livre docente of the Cardiovascular Surgery Discipline - UNIFESP - Paulista Medical School.

4. Full Professor of the Cardiovascular Surgery Discipline - UNIFESP - Paulista Medical School.

\section{Resumo}

A obesidade e as comorbidades desencadeadas ou agravadas pela mesma têm se tornado um problema de saúde pública. Diversas terapêuticas buscaram métodos capazes de reduzir de modo efetivo a massa dos indivíduos obesos e, conseqüentemente, atenuar as complicações a ela relacionadas. Dentre essas abordagens, nos últimos anos, os procedimentos bariátricos têm crescido de forma significativa, sendo capazes de promover reduções de massa expressivas e duradouras. Diversas complicações precoces e tardias são descritas e relacionadas aos procedimentos bariátricos restritivos e malabsortivos. Neste relato, descrevemos dois casos de complicações cardiovasculares (dissecção e aneurisma) no pósoperatório tardio de procedimentos bariátricos.

Descritores: Aorta/cirurgia. Cirurgia bariátrica/efeitos adversos. Aneurisma aórtico/etiologia. Aneurisma dissecante.

procedures. Each one of these proposals has different methods of action, outcomes, and complications, which are many times severe and lethal [2-4].

Reports have described cardiovascular changes, mainly valvular regurgitation and pulmonary hypertension, in patients treated for obesity with anorexic agents, such as fenfluramine and dexfenfluramine, drugs approved by the Food and Drugs Administration (FDA) so far. These descriptions have led to the withdrawal of fenfluramine $[5,6]$.

There are no reports of cardiovascular complications on ponderal losses after bariatric surgeries, especially the aorta ones.

In our Service, we found two cases of aorta complication after a fast ponderal loss caused by bariatric surgery.

Correspondence address:

Diego Gaia. Disciplina de Cirurgia Cardiovascular

Rua Napoleão de Barros 715 - $3^{\circ}$ Andar Vila Clementino - São Paulo

- SP. CEP: 04038-000.

E-mail: drgaia@uol.com.br 


\section{CASE REPORTS}

\section{Case 1}

We report a case of a 50 -year-old male patient, who has been hypertensive since his 20s. He had already had an acute myocardial infarction and two ischemic strokes without any complications. Previous treatment with anorexic agents and diet has failed. The patient was submitted to Capella's gastroplasty. His preoperative weight was 126.5 $\mathrm{kg}$. The procedure was recommended as a treatment of sleep apnea. Aorta echocardiographic and radiologic alterations were not noticed preoperatively. In moth 7 postoperatively, he was weighing $91.5 \mathrm{~kg}$ and presented a ruptured aneurysm of the ascending aorta. He underwent an ascending aorta surgical replacement. On the $22^{\text {nd }}$ day after bariatric surgery, he was weighing $73 \mathrm{~kg}$, arterial pressure was 140x80 mmhg and he was taking angiotensin-converting enzyme inhibitors, beta-blocker, and diuretics.

\section{Case 2}

We present a case of a 55-year-old male hypertensive and dyslipidemic patient. Previous treatment with anorexic agents and diet has failed. He was weighing $128 \mathrm{~kg}$ preoperatively. The procedure was recommended as obesity treatment and the patient underwent Capella's gastroplasty. Aorta echocardiographic and radiologic alterations were not noticed preoperatively. On the $10^{\text {th }}$ day postoperatively, the patient was weighing $91 \mathrm{~kg}$ and presented ascending aorta dissection, being submitted to ascending aorta surgical replacement (Figure 1). Currently, he is asymptomatic, weighing $81 \mathrm{~kg}$, arterial pressure of 120x70 mmHg and taking beta-blocker.

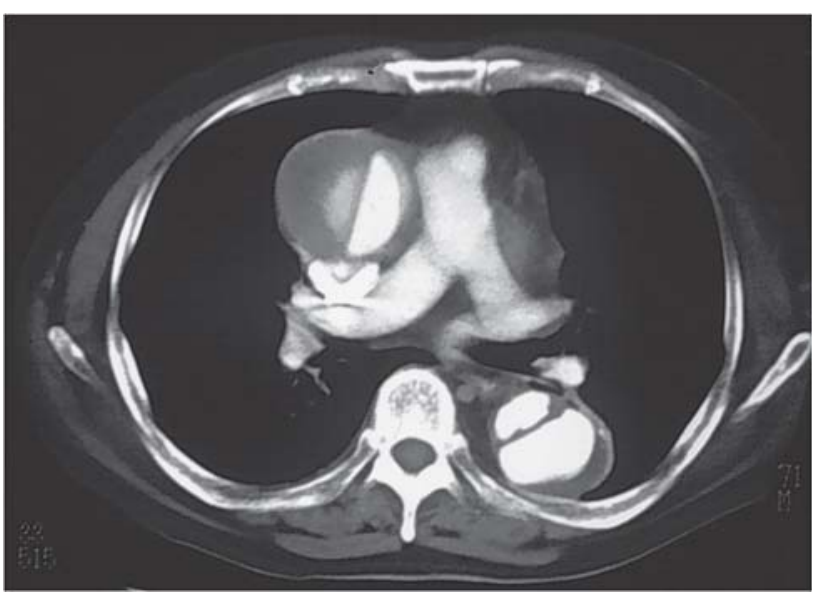

Fig. 1 - Chest computed tomography showing Stanford type A aortic dissection in a patient after bariatric surgery

\section{DISCUSSION}

Therapies previously proposed to treat obesity posed cardiovascular complications to some individuals, such as valve heart abnormalities $[5,6]$.

There are no reports regarding the long-term progression of patients who presented valve alterations with the use of anorexics. There are descriptions of regression of heart valve lesion after the withdrawal of fenfluramine, however, the patients had also their own previous body weight re-estructured and, therefore, it cannot be precisely defined whether the drug withdrawal or weight regain were responsible for the regression of the lesions [7].

With the advance of gastroplasty techniques, laparoscopic procedures and manifested weight loss, the number of interventions have been increasing in the past few years [8].

Despite the exciting results, many complications have been described for both restrictive and malabsorptive surgeries [2].

Weight loss induced by the procedure is not caused only by decrease of carbohydrates and fats absorption, what probably is benefic, but also at the expense of decreased intake of several basic dietary components, This can generate a cascade effect with unpredictable consequences in the long-term [9].

It is reasonable to admit that the reduced body index provided by such procedures can lead to a decrease in the intake of nutrients critical to the maintenance of an adequate homeostasis. Therefore, significant biochemistry changes in tissue building blocks could happen $[9,10]$.

Varieties of collagen are present in the arterial wall building blocks and its possible alteration, due to nutritional deficits found in the postoperative period of bariatric procedures, could contribute to the increased fragility of the walls already exposed over long periods to high pressure regimens and add one more risk factor to aortic dissections and aneurysms.

On the other hand, these individuals are part of the general population and, thus, they are also exposed to the risks of cardiovascular diseases, among them aortic dissection and aneurysms.

In the cases reported, the weight loss at the moment of cardiovascular event was similar (27\% in case 1 vs $29 \%$ in case 2 ). Time between procedure and event was also similar (7 months in case 1 vs 10 months in case 2 ).

Both patients also presented pressure control improvement and were normothensive at this point of the events, probably reducing the possibility of this risk factor to act as the only triggering risk factor to blame. 


\section{CONCLUSION}

The growing number of bariatric procedures has contributed for a significant percentage of patients with marked body mass index reduction; however, its long-term consequences are unknown. These two case reports are examples of patients undergoing a significant ponderal reduction presented aortic complications that might be related to such body alteration. Individuals undergoing bariatric procedures should keep a strict follow-up of the cardiovascular system, because they are possibly exposed to further risk factors.

Studies regarding nutritional alterations and arterial wall building block changes should be undertaken in order to clarify its occasional relation with the ponderal loss associated to bariatric surgery. Therefore, nutritional deficit could promote structural changes on aortic wall, making it more fragile and predisposing it to aneurysm dissection and dilation.

\section{REFERENCES}

1. Caterson ID, Gill TP. Obesity: epidemiology and possible prevention. Best Pract Res Clin Endocrinol Metab. 2002;16(4):595-610.

2. Msika S. Surgery for morbid obesity: 2. Complications. Results of a technologic evaluation by the ANAES. J Chir (Paris). 2003;140(1):4-21.
3. Carvalho PS, Moreira CLCB, Barelli MC, Oliveira FH, Guzzo MF, Miguel GPS, Zandonade E. Cirurgia bariátrica cura a síndrome metabólica ?. Arq Bras Endocrinol Metab. 2007;51(1):79-85.

4. Cunha LCBP, Cunha CLP, Souza AM, Chiminacio Neto N, Pereira RS, Suplicy HL. Estudo ecocardiográfico evolutivo das alterações anátomo-funcionais do coração em obesos submetidos à cirurgia bariátrica. Arq Bras Cardiol. 2006;87(5):615-22.

5. Cannistra LB, Davis SM, Bauman AG. Valvular heart disease associated with dexfenfluramine. $N$ Engl J Med. 1997;337(9):636.

6. Abenhaim L, Moride Y, Brenot F, Rich S, Benichou J, Kurz X, et al. Appetite-suppressant drugs and the risk of primary pulmonary hypertension. International Primary Pulmonary Hypertension Study Group. N Engl J Med. 1996;335(9):609-16.

7. Cannistra LB, Cannistra AJ. Regression of multivalvular regurgitation after the cessation of fenfluramine and phentermine treatment. N Engl J Med. 1998;339(11):771.

8. Deitel M, Shikora SA. The development of the surgical treatment of morbid obesity. J Am Coll Nutr. 2002;21(5):365-71.

9. Shai I, Henkin Y, Weitzman S, Levi I. Long-term dietary changes after vertical banded gastroplasty: is the trade-off favorable? Obes Surg. 2002;12(6):805-11.

10. Skroubis G, Sakellaropoulos G, Pouggouras K, Mead N, Nikiforidis G, Kalfarentzos F. Comparison of nutritional deficiencies after Roux-en-Y gastric bypass and after biliopancreatic diversion with Roux-en-Y gastric bypass. Obes Surg. 2002;12(4):551-8. 